\title{
EDUCATION LANGUAGE CHOICE OF HUNGARIAN ETHNIC DIASPORA COMMUNITIES IN VOJVODINA (SERBIA)
}

\author{
Tímea TROMBITÁS ${ }^{\mathrm{a}}$ Éva SZÜGYI ${ }^{\mathrm{b}}$ \\ ${ }^{a}$ University of Szeged, Department of Economic and Social Geography, Egyetem utca 2, H-6722 Szeged, \\ Hungary, trombitas.timea@gmail.com \\ ${ }^{\mathrm{b}}$ University of Pécs, Regional Development and Economic Doctor School, Rákóczi út 80, H-7622 Pécs, \\ Hungary, eva.szugyi12@gmail.com
}

Cite this article: Trombitás, T., Szügyi, E. (2019). Education Language Choice of Hungarian Ethnic Diaspora Communities in Vojvodina (Serbia). Deturope, 11(2), 54-74.

\begin{abstract}
Since one's surroundings and environment affect the extent to which one uses native language, first language use has declined and the native language use of the Hungarian minority living in ethnic diaspora communities also takes place of secondary importance in everyday situations. Native language cultivation is important, but it is also important to master the official language. Parents living in ethnic diaspora communities take these factors into consideration when choosing the education language for their children. The aim of the research is to identify, using "soft methods", the individual perspectives, motivations, and factors ("underlying background contents") according to which students and parents belonging to the Hungarian ethnic diaspora choose education language. The main question we pose in our work is what are the individual, familial, cultural and micro-community-related backgrounds in the education choices of Hungarian parents. We interviewed 42 students, parents, and educators of either Hungarian or interethnic backgrounds from ethnic diaspora communities in Vojvodina. According to the results, the native language use of students of the ethnic diaspora studying in the majority (official) language is in decline. The language of school and education has become Serbian, and the Hungarian language is mostly limited to use within the family or has lost its significance within the home completely; thus, it has been pushed to the background and is limited to a more "confined area" (such as communication with grandparents).
\end{abstract}

Keywords: ethnic (internal) diaspora, education, cultural and language diversity, interethnic relations, attitude

\section{INTRODUCTION}

It can be stated that languages in contact with each other interact and have an effect on each other, and this is more prevalent in heterogeneous ethnic communities, where the majority language has a stronger effect on the language use of ethnic minorities than vice-versa (Andrić, 2003).

In interethnic environments, members of a language minority are used to two- or multilanguage use, as both single-language or multi-language families, along with any family that speaks a different language from the one spoken in that environment, uses more than one language. First language use has declined and the native language use of members of the 
Hungarian minority living in ethnic diaspora communities also takes place of secondary importance in everyday situations. Use of the native language is important but it is also essential to master the official language since the ethnic environment demands that the individual use the language of his or her environment (Takács, 2008). Parents living in ethnic diaspora communities take these factors into consideration when choosing the education language for their children since education language plays an important role in questions of childhood and upbringing.

As a consequence of their distribution in the region, Hungarians living in ethnic diaspora communities have a unique position, as unique social-cultural values form within a community due to the co-existence of individuals of different ethnic, religious, linguistic and cultural backgrounds, in light of the effects they have to each other. This heterogeneous cultural environment raises many questions regarding education and language use.

Our work examines and interprets, the opinions and attitudes of parents, students, and educators living in ethnic diaspora communities in Vojvodina, regarding language choice in elementary school education, within the framework of a human geography study.

\section{Statement of the topic and the problem}

Many people have multiple national commitments and live in multiple nation states (Banks, 2004). Choosing a school and the education language for a child from a linguistic and cultural minority is a complex task, as parents making the choice for their children must face a number of dilemmas (Szügyi, 2012). One of these issues is about the language of education, because at school since education language influences the child's choices in education later on. This topic is quite controversial, as education language choice is a heavily debated issue both for laymen and experts as well (Árendás, 2012).

It has become the practice of parents in Hungarian ethnic diaspora communities to choose for various reasons - the majority (Serbian) language school for their children, despite the fact that Hungarian education is available for them (Joó Horti, Mengyán Pletikoszity, Csernik, \& Badis, 2014). Approximately, 20 percent of elementary students of a Hungarian minority background studies in Serbian (Djurdjev, Kicošev, \& Vuksanović, 2003); moreover, in certain isolated Hungarian ethnic diaspora communities, more than 50 percent of Hungarian minority students study in Serbian. ${ }^{2}$

\footnotetext{
${ }^{2}$ Strategy for Education Development 2010-2016, Hungarian National Council
} 
The issues related to the coexistence of groups with different cultural and linguistic backgrounds have long been in the forefront of human geography. The relevance of the topic is justified by the fact that transitological changes related to the transition have brought minorities and minority-related topics into the foreground of research. A part of the research examines the effects of the 1989-1990 period on education, educators, and social groups participating in education (including minorities) (Kozma, \& Tözsér, 2016). Furthermore, nowadays there is a greater social and scientific interest in questions about ethnicity and its local processes, focusing on the topic of social diversity (Kovács, 2017; Balizs, 2015). Nevertheless, thanks to the changes in recent years, the results and theoretical approaches of other social sciences are gaining ground in social geography (Boros, 2008). Besides, according to Hagget (2006), those geographers who want to understand the cultural diversity of the world cannot disregard the studying of languages.

\section{The aims and questions of the research}

The general aim of the research was to identify the individual perspectives, motivations, and factors ("underlying background contents") of students and parents - belonging to the Hungarian ethnic diaspora - of choosing an education language. Furthermore, we also considered it very important to uncover the educators' opinions about the difficulties of choosing education language for the students.

The main question is the following: what are the individual, familial, cultural and microcommunity-related background factors of the education choices of Hungarian parents in Hungarian ethnic diaspora communities. Further questions developed from this, such as: What dilemmas must students and parents face by choosing an education language? How do individuals living in interethnic families define their position on language education choice?

Our research does not aim to take position with or against either majority or minority language education. In each case, the choice of education language is a subjective one, since every family has a unique position, background and circumstances, and their decisions and choices must be fully respected.

\section{THEORETICAL BACKGROUND}

In the majority of Europe's ethnically heterogeneous countries the most often generally propagated language politics is bilingualism. Bilingualism applies to most of humanity as knowing a language different from one's mother tongue broadens one's horizons, making one 
more empathetic towards different cultures and identities. According to Grosjean (1982), bilingualism means using two (or more) languages regularly. An individual can be considered bilingual if, during the course of his or her everyday life, he or she needs and uses two (or more) languages (Grosjean, 1982).

Bilingualism is a natural and implicit phenomenon in heterogeneous, multifaceted ethnic and linguistic communities (Andrić, 2004; Balizs, \& Bajmócy, 2015). It is a usual occurrence in many places and is also widely accepted that children can acquire two or even more languages without great effort (Petitto, Katerelos, Levy, \& Gauna, 2001). Yet, a different line of reasoning also exists, according to which bilingual acquisition could have a negative effect on the development of the child (MacNamara, 1967).

According to Skutnabb-Kangas, for minority individuals, the failure to become bilingual could have fateful consequences. The author identifies three typical cases of unsuccessful bilingualism (Skutnabb-Kangas, 1981). In the first case, the individual remains unilingual and the native language remains dominant, thus limiting further education for the individual. In the second case, the perfectly acquired and mastered second language dominates and the individual forgets his or her native language or speaks it poorly. In this case, there is a good chance that this individual will become estranged from the ethnolinguistic group it belonged to previously - he or she may feel uprooted, and ethnic belonging may become problematic. In the third case, the individual speaks both languages poorly and the previously mentioned problems cumulate (Skutnabb-Kangas, 1981).

Many factors can play an influential role in education language choice in minority communities (Schneider, \& Buckley, 2002; Malmberg, Andersson, \& Bergsten, 2013; Papp, 2014). The choice can further be made more difficult wheter the ethnic group whose individuals live in proximity to one another or if they are dispersed in smaller ethnic diaspora communities. Thus, we can examine education language choice from various perspectives (Papp, 2014; Ferenc, 2013). Taking pragmatic views into perspective, we can differentiate between symbolic (language and culture) and rational (school facilities) motivations. Furthermore, considering the minority community's distribution in the area, we can differentiate between the motivations of those living in close proximity to one-another and the motivations of those living in ethnic diaspora communities. We can also differentiate between the motivations of individuals (parent, student, teacher) who play a role in the decision-making process when choosing education language (Papp, 2014).

Previous studies on the theory of choosing education language at schools or choosing schools in general, grouped the explanations for the uniqueness of minority education on macro-, 
mezzo- and micro levels (Papp, 2014). Under the macro level, those school choice motivations are meant which concern the education system as a whole, while mezzo means the factors that are closely connected to the school. Under the micro level, individual motivations are considered. This study is connected to the micro level described by this system, as it researches individual motivations behind education language choice.

When making this crucial decision, parents, students and educators (who in some cases must advise the parents) have to weigh and consider many factors, as this decision could have an effect on the child's life, and its development and relationships within the community and family. One of the main functions of education is cultural cultivation since through it, the accumulated knowledge, values and norms of society are passed on to the younger generations (Bourdieu, 1996).

\section{The connection between social mobility and education language}

We would like to highlight three factors to demonstrate that choosing education language puts parents, students and teachers in a difficult position. They include the connection between social mobility and education language, the effect of the chosen education language on forming identity, and the ethnic background of the family (for example, partners of different ethnicities).

Minority parents who are about to make the choice of education language consider it an important question if their children will be more successful in life after studying in their native language or in majority (official) language. From the perspective of a minority, deciding on which school to choose does not only determine the language of instruction, but it also results in a language selection (Göncz, 2014; Priestly, 1994).

From the perspective of minorities, social mobility is closely connected to proper knowledge of the official language, as, if an individual of a minority background does not successfully acquire the official language, he or she will be limited in terms of gaining position in a career. The official language, as the language of assertion, has a defining role, which is why a number of minority parents consider official language education as the key to successful social and career assertion. Thus, in choosing the official language ("the language of authority"), we can observe the strive for social recognition. It is, therefore, worthwhile to examine the connections between social status and education language, since, in choice of education, the parents strive to help their children achieve their own social status or a level higher than their social status (Andor, \& Liskó, 2000). For this reason, the question of education language choice is a difficult 
one, since many parents believe that their children will have better opportunities if they begin their studies in the official language.

\section{The effect of the chosen education language on identity forming}

The chosen school, the education language and the curriculum are determining factors of the identity development of the student, as language is a complex "phenomenon", which is not simply a tool of mediation, but an integral part of personality or identity (Göncz, 2006). School choice will have an effect on the later development of the child's identity since a class operating in a given education language also plays a role in identity forming (Árendás, 2012).

According to Attila Papp, the education choice for a child is formed consciously by the parents or are determined by environmental influence. These decisions have a social, public benefitting and economic relevance (Papp, 2013). From the perspective of the minority, decisions related to education language choice can be broader with further individual and unique perspectives, because it can result in language switching, as after a certain time, native language can lose its priority in use to the majority (official) language, and the language of the parents can become foreign for the children (Papp, 2013).

\section{The ethnic background of the families}

Studying in one's mother tongue is not obvious in every case, not even if laws allow education in minority languages, since a number of factors have to be taken into consideration in choosing a school, such as the family's cultural/language attachments or the linguistic abilities of the child. An important role is played by the incorporation of ethnicity of the parental family, or the presence of ethnically mixed marriages, friendships or relatives. In an ethnic diaspora community, these factors are more significant. According to Bernstein (2002), the language development of a child is strongly influenced by the environment and the community in which he or she is raised (Bernstein, 2002). In diaspora regions, the number of two-language, interethnic marriages are on the rise, and in these cases, it is more difficult to decide which parent's language the child will consider as his or her own. But in de Klerk's (2001) study, the success or failure of "family language politics" in the case of mixed-ethnicity partners depends mostly on parental commitment and on maintaining the "cultural background" highly influenced by external factors, such as historical, social or political factors (de Klerk, 2001). Aside from this, the family as a micro-community has a unique dynamic force field, in which individual relationships form (Vajda, \& Kósa, 2005). 
From parental perspective, the choice of education language (language choice) can be tied to the prestige of languages; that is, to those "imagined or real ideas" that hold that one of the languages would allow more successful career opportunity for the child (Papp, 2013). In the case of parents with two or multiple ethnic, linguistic or cultural ties, a special situation emerges, especially because the parents often have different past experiences in education one parent might have completed his or her studies in the minority language, while the other in the official language (Árendás, 2012). Choosing an education language is a very difficult decision in these cases since school enrolment is not a natural or automatic process, like the one that may appear in homogeneous ethnic families (Árendás, 2012). Previous research shows that in the case of mixed-ethnicity marriages, school choice most often results in majority education language (Dobos, 2011).

\section{DATA AND METHODS}

\section{Research area}

Autonomous Province of Vojvodina is located in the northern part of Serbia. Vojvodina, as border region offers an interesting case of study for questions of ethnicity and cultural. In the socio-cultural terms of Vojvodina, the region is a unique multicultural, multi-ethnic area, not only in Serbia but also in Europe, regards the ethnic and religious background of its population (Djurdjev et al., 2003; Kovačević, Zakić, \& Bubalo-Zivković, 2010; Léphaft, Németh, \& Reményi, 2014). One of the characteristics of the border regions is mixed ethnic population (Đerčan, Bubalo-Živković, Solarević, \& Šabić, 2017; Szügyi, 2013). As in the course of history, as well as recent days, individuals with various backgrounds, religion and native languages live here, and more than twenty ethnic groups can be found (Hajdú, \& Szügyi, 2015). Aside from the members of the majority nation (Serbians), Hungarians, Slovaks, Croatians, Montenegrins and Romanians also live here in greater numbers. Six languages are in official use in the region of Vojvodina, which reflects the region's multi-ethnic and multilingual composition. Besides the Serbian language, these include Hungarian, Slovakian, Romanian, Rusyn and Croatian.

According to the 2011 census, 253,899 person claim Hungarian ethnicity in Serbia, of which 251,136 individuals live in Vojvodina. ${ }^{3}$ In territory of Vojvodina 230,444 individuals consider Hungarian to be their mother tongue. ${ }^{4}$ In comparison to the total population of the country, the

\footnotetext{
${ }^{3}$ Statistical Office of the Republic of Serbia (RZS), 2011

${ }^{4}$ The Republic of Serbia: The Third Periodical Report on the Implementation of the European Charter for Regionalor Minority Languages in the Republic of Serbia, Belgrade, December 2014, 18 p.
} 
Hungarian minority makes up 3.5 percent of the population, while amounting to 13 percent of the population of the region of Vojvodina (Kapitány, 2015). However, in comparison with the 2002 census data, the Hungarian population has decreased by 39,400 individuals by $2011 .{ }^{5}$

The Hungarian minority of Serbia lives mainly in municipalities in the northern part of Vojvodina, in areas close to the Hungarian border along the river Tisza (Kocsis et al., 2006). The most concentrated areas of ethnic Hungarians can be found in the north-eastern part of Bačka, on the right side of the Tisa, in the Horgoš - Bačka Topola - Bačko Gradište triangle (Kocsis, \& Kocsis-Hodosi, 1998). Within Vojvodina, region of Bačka has the largest population of Hungarians, their number is significantly less in Banat area, while in Srem region are only a few isolated Hungarian communities (Fig. 1).

Figure 1 The proportion of Hungarian natonality per municipality in the territory of Vojvodina (based on the 2011 census data)

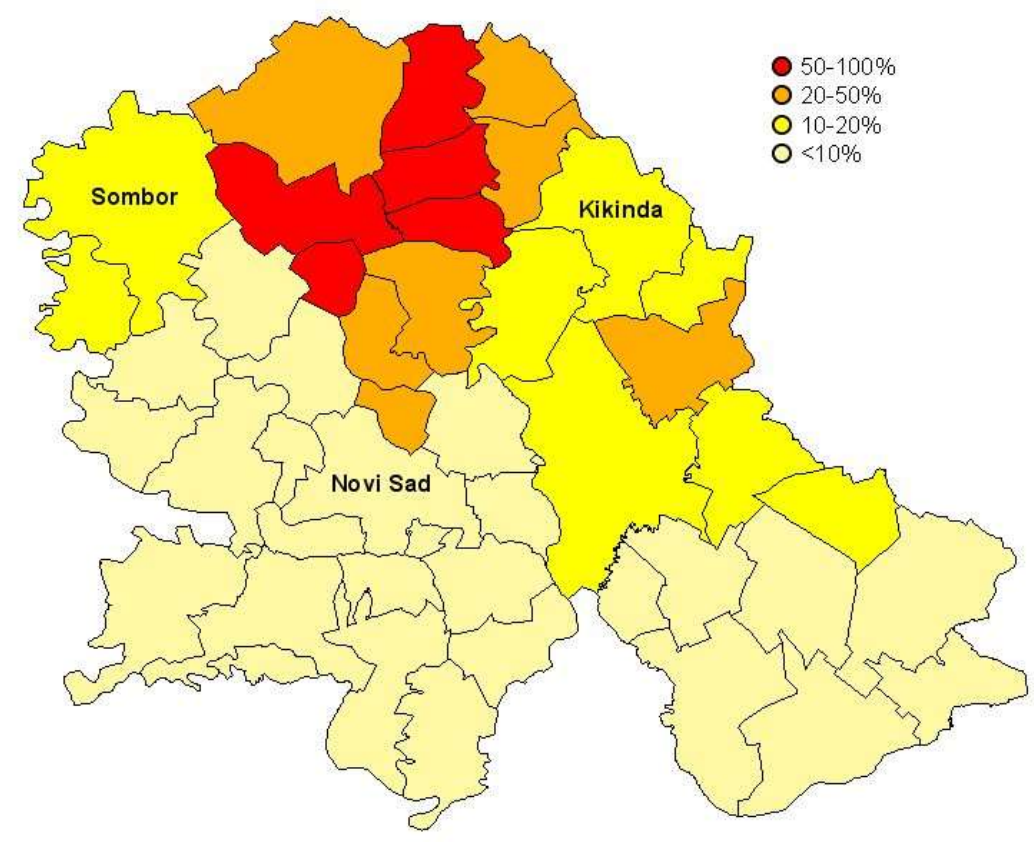

Source: Edited by authors

\section{Research methodology}

Research of ethnic diaspora communities, minorities, and minority education usually requires an interdisciplinary approach, as these topics concern the various disciplines of geography, history, demography, ethnography, culture, politics, law, etc. We applied an interdisciplinary approach to work out our research questions. Aside from relevant works within the field of 
geography, we used relevant results and research from the disciplines of linguistics, pedagogy, economics, history, and sociology to develop certain chapters. However, it should be noted that geography is suitable for interdisciplinarity and for approaching complex scientific questions (Mészáros, 2014; Kovács, 2017).

The data used in this work is collected from the database of the Statistical Office of the Republic of Serbia. During the collection of secondary data, we strove to process all available relevant literature of this topic at hand. Beyond this, other important sources (for example laws, statistical reports, strategic and development documents) were also used.

In conducting the empirical research, we used a qualitative (interview-based) method, which allowed the interviewed individuals to express their opinions more freely. We also interviewed students, parents, and teachers with Hungarian or mixed-ethnicity backgrounds, who are living in Hungarian ethnic diaspora communities. The research was conducted in the areas of Kikinda, Novi Sad, and Sombor municipalities, where both Hungarian and Serbian language primary school education existed at the time of the research- thus, students and their parents had a choice of choosing an education language.

Thanks to research scholarships ${ }^{6}$ and grants ${ }^{7}$, in 2013-2014, we conducted interview-based research in three municipalities ${ }^{8}$ considered to be diaspora townships. During this time, we interviewed elementary school teachers, students, and their parents about the reasons behind their education language choice. In total, 42 interviews were conducted in the three sample areas: 13 in Kikinda, 14 in Novi Sad, and 15 in Sombor. In the study, we used structured (students) and semi-structured interviews (parents, teachers), and in the case of interviews with teachers, we also asked questions about the teachers' own personal career and about the education of their own children. The methodology used in the empirical research is based on a method that was developed in a previous research, which was conducted in 2012 and 2013 in Vojvodina and in other regions in the Carpathian Basin. ${ }^{9}$ Considering this research we applied

\footnotetext{
${ }^{6}$ The research title was "Majority language school choice", which was supported by the 2012-2013 DOMUS tender of the Hungarian Academy of Sciences.

${ }^{7}$ The research in Novi Sad and Sombor were supported by the European Union and the State of Hungary, cofinanced by the European Social Fund in the framework of TÁMOP-4.2.4.A/ 2-11/1-2012-0001'National Excellence Program'

${ }^{8} \mathrm{~A}$ municipality (opština) is the lowest level governmental (administrative) unit in Serbia, which usually includes a larger township (city) and its agglomeration. The center of it is the seat of the municipality (Vujadinović et.al.,2016; Nagy, 2015).

${ }^{9}$ The researchentitled „Majority language school choice”, supportedby the scholarship of the Hungarian Academy of Sciences (Domus)
} 
the developed topics, methodology, sampling and interview questions in our research in the selected municipalities.

In terms of the population of the examined sample areas, Novi Sad is the largest area, followed by Sombor and Kikinda. The selected areas are municipality seats; thus, the research was conducted in urbanized areas among urbanized population. However, it should be noted that the urban environment helps individuals in adapting to the dominant majority language, and the change of spoken language is a more common phenomenon in cities than it is in rural areas, where the minority language speakers live in more concentrated areas (Laponce, 1987).

Two important factors played a role in selecting the sample areas (municipality seats). The first criterion was the availability of both the Serbian and Hungarian education languages, while the second criterion was the geographic position of municipalities ("regional position"). In addition, for the purpose of the research, ethnic diaspora community meant a community with a minority population of less than 30 percent of the total population.

In accordance with the applied methodology, students of the upper elementary classes of Hungarian or interethnic backgrounds studying in Serbian language participated in the research. Interviews were also conducted with the students' parents and teachers. Some teachers interviewed in the Sombor sample area also worked in high schools beyond the elementary school.

Finding the interviews for the research began through personal connections, followed by the "snowball method", according to which the researcher gathers data from the population of interest and asks about other possibly interested individuals (Babbie, 2008). Thus, during the research, we were able to interview acquaintances of the original subjects they recommended. Firstly, we interviewed teachers, then, using their recommendations, we conducted interviews with students, who in turn helped us to contact their parents for further interviews. In the majority of the cases, we were able to reach the parents directly (through personal connections).

Two major difficulties were encountered during the research. It was difficult to find families whose members were connected to Hungarian roots, but their children were educated in Serbian language. Since there is no public statistical database from which "Hungarian-roots parents" choose Hungarian or Serbian language, therefore the sampling procedure was started through a personal contact network, and then I reached the subjects of the interview using the above mentioned "snowball" method. There was another problem that many of the parents refused the interview.

From the aspect of the research, I considered everyone to be Hungarian nationality who declared themselves as Hungarian. I would like to emphasize that it is not always easy to define 
the issue of nationality for the people, who are living in diaspora areas. Several interviewees were uncertain in their nationality, there was noticeable a kind of intermediate or dual identity, because the parents came from mixed nationality marriages, or even now they live in mixed marriages.

The questions of the interview can be categorized into five larger categories. They concern the familial background, school pathway, characterization of school, social relationships, and the students' future plans. To adapt to the subjects' command of language and request, the interview was conducted in both Hungarian and Serbian. The research mainly mirrors the teachers' and parents' opinions and attitudes because we received the most information from these two group of subjects during our research.

\section{The dilemma of defining "ethnic diaspora"}

The situation of diaspora extends to a wide range of population and historical predicaments (Clifford, 1994). To understand the concept of "ethnic (internal) diaspora", the term "minority" has to be explained. The dichotomy of "majority-minority" in everyday use marks demographic proportions, according to which one group is larger than the other. The concepts of "majority" and "minority" are used to mark population proportions in our study. In the paper, "majority language" means the Serbian language, the official language, while "minority language" means the languages of minorities living in Serbia, the language of the Hungarian minority among them.

A number of researchers have considered methodological dilemmas of diaspora and raised multitude questions of categorization issues (Clifford, 1994; Brubaker, 2005).For this reason, it is very difficult to find a unified definition for general term of diaspora. In this study we used the term of ethnic (internal) diaspora. It is also hard to define the concept of ethnic (internal) diaspora, as the concept itself is multifaceted and complex, and no exact definition for the term (Bodó, 2010; Ilyés, 2007).This term is mostly used for the Hungarian communities, who are living in neighboring countries of Hungary, in Carpathian Basin, and they do not live in ethnic block.

From a methodological perspective, there is no precise definition about the size of the population that could be considered to be an internal diaspora in a township or a region, as opinions differ and vary according to country. When defining an internal diaspora community, it is important to take the absolute size of the Hungarian population into consideration, along with the size of the majority population(s), and the extent of the dispersal (distribution) in the area as well (Ilyés, 2007; Tátrai, 2017). 


\section{The characteristics of minority education in Vojvodina, focusing on the Hungarian minority}

Elementary education is compulsory and free in Serbia. It is divided into lower (1st to 4th) and upper (5th to 8th) grades. Elementary schools were established by the state, which also finances their operation. As far as founding laws are concerned, the recent changes that have had an effect on the Hungarian community include the fact that the Hungarian National Council has taken over the foundation rights to certain institutions and has received the right to treat some of them as institutions of special importance.

There are three fundamental legal documents about education in Serbia: The Law on Primary Education $(2003 / 04)^{10}$, the Law on Secondary Education (2003 and 2005) $)^{11}$, and the Law on Post-Secondary Education (2005). According to changes in 2002, education has become decentralized, thus, education is now also under the Provincial Secretariat for Education and that of local governments.

According to the Law ${ }^{12}$, education can be uni- or bilingual. Education language in Serbia is primarily Serbian, but, under certain circumstances, national minorities can also have access to education in their own language (Filipović, J., Vučo, J., \& Djurić, Lj., 2007). ${ }^{13}$ Those who do not have access to public education in their mother tongue (Ukranian, Macedonian, Bulgarian, Roma, Bunjevac) also have the right to nurture their native language. In the elementary schools of Vojvodina, education is offered in the following-mentioned six languages: Serbian, Hungarian, Slovakian, Romanian, Rusyn and Croatian, as well as bilingually - in Serbian and in one of the minority languages. ${ }^{14}$ Native language classes, containing elements of one's ethnic culture, can also be chosen in Ukranian and Roma languages.

When making arrangements for minority education, the number of students and the number of available educators are taken into consideration. If there are fifteen students who enrol, the institution is obligated to open a class in the minority language, while in the case of fewer applicants, classes can be opened with special permission in some schools. Education in a minority language is currently present in 539 elementary schools and 110 secondary schools in Vojvodina, however, the number of students studying in a minority language decreases every year (Szerbhorváth, 2015)

\footnotetext{
${ }^{10}$ The Law on Primary Education ("Sl. Glasnik RS", br. 88/2017 i 27/2018)

${ }^{11}$ The Law on Secondary Education("Sl. Glasnik RS", br. 55/2013 i 101/2017)

${ }^{12}$ The Law on Primary Education

${ }^{13}$ The education law (7th paragraph) states that education language is Serbian, but minorities can study in their native language, in exception a lcases in Serbian. (Molnár Gábrity, I. 2008).

${ }^{14}$ The Law on Primary Education
} 


\section{RESULTS OF THE INTERVIEWS}

The results show, that in all three of the sample areas the interviewed students usually use the Serbian language within their families for the most part, and Hungarian is used rarely or not at all. For this reason, the parents who participated in the research found it natural to enrol their child (ren) into classes where Serbian was the education language. ${ }^{15}$ The interviewed parents disclosed that they did not really consider education language just enrolled their children in Serbian classes automatically.

In the following part of our research, we will outline three factors from the results of the empirical research, which were determining ones on the side of education in the Serbian language. They include the chance of later success, parental help in studying and the parent's own negative/positive experience(s).

\section{Chances of later success}

Education language and school choice is one of the central themes in the society of a minority community, because they are hoping their choice leads to positive school advancement and a better job position. Individual choices related to education were decidedly influenced by perceived chances of later success in terms of career. This was the main reason for number of parents to enrol their children in majority language class. A kutatásba bevont szülök evidensnek tartották, hogy a gyermeküket szerb osztályba íratták. ${ }^{16}$ Parents involved in the research found it evident that their children were enrolled to Serbian class. It is also releated that the interviewed children went to a Serbian kindergarden and had to already spoken Serbian, so the parents considered it correct if they children would go to a Serbian language class.

To the question of why Hungarian parents would enrol their children in Serbian class, in general the parents feel that if they live in Serbia, they would rather enrol their children in a Serbian language class, mostly due to hopes of later success. Many parents have disclosed that they had trouble adjusting to the Serbian education language in their own secondary school studies after finishing elementary school in Hungarian and they did not enrol in post-secondary studies because of this. Therefore, parents think that it is more beneficial for their child to encounter Serbian in elementary school so that they can achieve more in the future. Teachers meet and speak with many parents during the enrolment process. Therefore, according their experience, due to the effects of the Serbian environment, the parents believe that their children will be more successful if they study in Serbian since they will acquire the official language "perfectly", which will be an advantage later on.

\footnotetext{
${ }^{15}$ The opinion of the interviewer-researcher

${ }^{16}$ The opinion of the interviewer-researcher
} 
"...it's mainly because of the environment that they think they will be more successful if they complete their education in Serbian" (interview excerpt, teacher-U2, Novi Sad, 2014).

"... if the child learns Serbian well and stays in the country, he will be successful." (interview excerpt, parent-U12, Novi Sad, 2014).

"... because we were certain that she would study in Serbian, so she would have a wider choice [of further education and career choice]..." (interview excerpt, parent-Z15, Sombor, 2014)

According to several opinions, it is vital that one should acquire the official language, as without it, it is much more difficult to be successful in further education, an in labour market. In some cases happened, that the parent discloses that after his child began his studies in Serbian in the first grade, the parent realized that he does not have a strong enough command of the Serbian language to help his child, despite the fact that the parent uses the Serbian language in work situations almost exclusively. According to the parent, he lacks the type of information that would have been acquired during one's own education. Since the parent completed his studies in the Hungarian language, he felt it was difficult to help his own child in the child's studies. Considering the parent's own opinion, these difficulties can be compensated for by the fact that in the child's further studies he will be more successful and the parent would like it if his son would be successful in his own hometown.

"...I had thought I knew Serbian well, and when my son began first grade, I realised that I don't really know Serbian because I only speak everyday Serbian, and I am missing a certain kind of knowledge. I will never learn grammar properly, I don't even care about it, I never liked Hungarian grammar either. For this reason, I'd like it if he were more successful, and if he were successful here. Easier for him to have a break here, to choose between options." (interview excerpt, parent-U13, Novi Sad, 2014)

"...you should speak the language of the country you are living in. No other minorities in our greater vicinity have as many rights as we do, we can still choose if we want to study in Hungarian until the end of high school. University is a question, of course, and it's not just Hungarians who can choose. Of course, it could always be more." (interview excerpt, parentU13, Novi Sad, 2014)

Similarly, a father from Sombor also chose Serbian as the education language for his child, with hope of later success. He also considers it very important to acquire the official language to the level of native language. The parent argued that many acquaintances emigrated to work abroad and their children are receiving education in German, the official language where they are.

"If you leave to work abroad, as a minority there, you must know the official language. Everyone's children attend German school, preschool." (interview excerpt, parent-Z10, Sombor, 2014) 


\section{Parental help in studying}

During the study in Novi Sad, an argument was presented that parents chose Serbian education language because they worried that they could not help their child in their studies in the Hungarian education language. Teachers also mentioned that parents of Hungarian ethnic background studied exclusively in Serbian after elementary school, speak Serbian at work, and they worry they cannot help their children during their studies in Hungarian. Teacher disclosed that Hungarian ethnicity family enrolled a child in Serbian language education, but the child could not adjust to it, so the parents re-enrolled him in a Hungarian class. However, a problem arose because both parents had completed their education in Serbian and they could not help their child study in Hungarian and therefore, they had to hire a tutor to help their child.

"One of the boys from the school was enrolled in Serbian class, but he could not fit in, so the parent enrolled him in Hungarian class, but it's difficult for the child, a tutor comes over, a private one, because the parents cannot hold the front, he can't follow the lessons, they can't help him. The father is an engineer, he attended school in Serbian, they speak Serbian at home, but their daughter was also enrolled in Serbian class." (interview excerpt, teacher-U3, Novi Sad, 2014).

Aside from the fact that parents "automatically" decided to enrol the child in a class with Serbian as the education language, fear also played a factor in the decision-making process as they thought if the child were enrolled in Hungarian class, the parent could not help with studying. Besides this, the biggest argument for Serbian education language enrolment was that the child would have better opportunities later on in choosing high schools or even universities.

"The Serbian line is pretty strong here, parents don't want to bother with the Hungarian. We don't speak it that well anymore, I couldn't help my daughter, there wouldn't have been anyone to study with her at home." (interview excerpt, parent-U14, Novi Sad, 2014).

In several cases, fathers with "Hungarian roots" told us that family chose Serbian language education because fathers work a lot and spend little time at home, so they did not speak much Hungarian with their children. Mostly their wife was with the children in their early years at home and she spoke with them in Serbian language, thus, they acquired Serbian to a greater degree. As a consequence, the children were enrolled in a Serbian education language class, because they spoke Serbian better than Hungarian. In this case, the question examined in Zsuzsanna Árendás's work is proven. According to her work, education and education choices can be connected to gender, as practicing and studying at home with the children is traditionally the mother's task and is related to education language choice (Árendás, 2012).

“... I work a lot, I'm not home much with the children. My wife only speaks Serbian and she's at home with them more, and so the children learned Serbian better. If they were to attend Hungarian class, I couldn't have helped them with studying because I'm not at home, and my 
wife, as I've said, doesn't speak Hungarian, so we thought it is better to enrol them in a Serbian class..." (interview excerpt, parent-K11, Kikinda, 2013).

\section{The parents' experiences}

The parents' experiences acquired during their own education play a determining role in choosing the children's school and education language. During the research, some parents have completed their elementary and secondary studies in Hungarian language explained the reasons for which they thought Serbian education language was a better choice their child. They disclosed some reasons, which played a role in their decision. One of the reasons is that during their own education, especially during their secondary school/university years, the Serbian language posed a difficulty for them, which was a fate they wanted to spare their children from, by enrolling them in a class with Serbian as the education language. The other reason was their own family/friend experiences studying in the Serbian language which by their opinion, greatly influenced their positive experiences in life.

“...for me, the choice was made a long time ago, that if I have children at all possibly, I wouldn't educate them in Hungarian if we stay here in Serbia. So for me, the first reason was me, what I experienced [the difficulties during my university years], in Hungarian, and after I didn't have as many choices, or I would've had to choose something I don't like, just to study in Hungarian or something I like, but in Serbian, and the difficulties were automatically doubled. The other fact is my younger brother. He finished elementary school in Hungarian but began secondary school in Serbian. When he had to choose a school, he decided to try in Serbian. He had studied some Serbian in school and spoke it in his environment, so he knew the everyday language, but the specialized terms were missing there too. So he completed his first year of secondary school getting twos and threes because of the language, mostly because of the language, but he completed it. As the years passed, he got better and, of course, he learned the language really well..." (interview excerpt, parent U-12, Novi Sad, 2014).

The mother points out that after secondary (grammar) school, she could only continue her studies in Serbian, or she would have had to choose a university or college programme that was available only in Hungarian language, one that she was not interested in. This posed a great dilemma for her. In the end, she began her university studies in Serbian, which, in her opinion, was twice as difficult, due to her lack of Serbian knowledge. In her appraisal, she speaks the Serbian language well, as she even had ancestors of Serbian ethnicity, but despite this, her knowledge of Serbian is not excellent. She points out that she struggled a lot with the language in her university years, and she wanted to make sure his son will avoid this problem, so she enrolled him in a school with a Serbian education language. In this case, it is evident that the mother is not satisfied with her own education in Hungarian and so she "changed" the situation and chose to educate her child in the Serbian language. 
„,... so I completed elementary and secondary school in Hungarian, and started university in Serbian, because there was only Hungarian in the Hungarian Language and Literature Department, and it was at university that I saw just how important it is to study Serbian in school because we live in Serbia, so we should know the language, and it could have been stressed a bit more. In both elementary and secondary school I had teachers who weren't really into the idea that children should learn the [Serbian] language, and since the lectures were in Serbian or in German, this wouldn't have been a problem, but since my German wasn't at the level that I could say everything in German, I chose Serbian instead, but the specialized terminology and such, when I went home, I was translating from Serbian to Hungarian, so that I could understand what I had to study and learn, well, it was difficult and I spent a lot of time doing this" (interview excerpt, parent U-12, Novi Sad, 2014).

A parent raised in Temerin but nowadays living in Novi Sad also recall, that it was in part due to his own negative experiences in education that he chose Serbian as the education language for his child, to make it easier for him to be successful in his later life. The father pointed out that when he had to choose secondary school, he had not decided based on his interests, but rather on education language - which programmes were available in Hungarian. He has regretted this decision. Today, he believes he would choose to study something that interests him and he would not base his decision on education language. Furthermore, the interviewed father also discussed the difficulties of observing his own sister, who was studying in Serbian in secondary school. For these reasons, the father thought it wiser to educate his child in the Serbian education language from elementary school.

"I chose the school I chose because I wanted to study in Hungarian, but I consider this a mistake now. It's a mistake because we really should choose what we like... for example, some who spoke Serbian worse than me chose to study in Serbian, but I didn't want to. They open Hungarian classes for the Hungarian students, I thought and went to such a class, where, I'm not going to say I wasted three years of my life, but almost. I didn't want to go to a Serbian class, I also saw my sister, who went to a Serbian secondary school, she struggled with it a lot, she struggled with Serbian..." (interview excerpt, parent-U13, Novi Sad, 2014).

\section{CONCLUSION}

As the theoretical background shows the ethnic diaspora students studying in the majority (official) language speak their native language less and less. Serbian has become the language of school and studying, thus the Hungarian language has been pushed to the background and is limited to a "confined area" (for example speaking with grandparents).

According to the practical implications, the students we interviewed come from Hungarian or interethnic families and consider Serbian, rather than Hungarian, as their mother tongue. The students (with one exception) claim to struggle with the Hungarian language. The majority of the students communicate in Serbian with their parents, grandparents, siblings and friends. For these students, with the exception of one boy, it did not pose any difficulty to begin their studies 
in Serbian as the education language, since they use the Serbian language for everyday communication. The research shows, that in most cases, the chosen education language is aligned with the language in use in the family, so the interviewed students studying in Serbian did not experience difficulties in studying in the official language.

Based on the practical researches we can state that children speak the official language better than Hungarian. In these cases, the parents find it completely natural to educate their children in the Serbian language, furthermore, they would like to continue their education in Serbian as well. In the majority of these families, the process of transmittance of the Hungarian language has been interrupted and the Serbian language has become dominant. The language knowledge of the children would not made it possible to study in Hungarian, so insufficient language knowledge influences education language choice.

Based on empirical research, in most cases, individuals who decide on majority language education consider participation in minority language education to be a social disadvantage, an obstacle to later-life success. In the case of children from interethnic marriages, choosing education language is even more difficult, but most often there is an "adjusting" to the Serbian parent's language and parents choose the Serbian education language for their children, especially in municipality seats, or urban areas. On the other hand, in Hungarian-majority village (rural) areas, children from mixed-ethnicity marriages are often enrolled in Hungarian schools, thus, within a town, the majority language of the area is connected to the ethnic proportion and influences the family's education language choice. In the opinion of the majority of teachers, in the case of children from interethnic marriages, the fact that the children are raised in two cultures should be a benefit to the child - it should be an advantage.

Aside from the factors of school proximity and family traditions, parents choosing a school for their children took some factors influencing school choice into consideration. Due to the child's "better" knowledge of the Serbian language, they thought it natural to choose Serbian as the education language (automatic); considering later-life success, they enrolled their children in classes with Serbian as the education language. Offering help while studying at home (doing homework) was also proven to be an important factor, along with the parents' own negative experiences in making education-related choices.

\section{Acknowledgement}

The empirical research is supported by the DOMUS tender of the Hungarian Academy of Sciences and the European Union and the State of Hungary, co-financed by the European Social Fund in the framework of TÁMOP-4.2.4.A/2-11/1-2012-0001'National Excellence Program'. 


\section{REFERENCES}

Andor, M., \& Liskó, I. (2000). Iskolaválasztás és mobilitás. Iskolakultúra: Budapest.

Andrić, E. (2003). A szerb nyelv hatása a magyar általános iskolás tanulók nyelvére Vajdaságban. In Gábrityné Molnár, I., Mirnics, Z. (Ed.), Kisebbségi létjelentségek: Szórvány- és szociolingvisztikai kutatások (pp.193-214). Magyarságkutató Tudományos Társaság: Szabadka.

Árendás, Z. (2012). Az iskolaválasztás elbeszélései. Társadalmi Együttélés, 2012/1. Retrieved on 2011/05/05 from http://epa.oszk.hu/02200/02245/00001/pdf/EPA02245_Tarsadalmi_ egyutteles_2012_01_Arendas.pdf

Bodó, B. (2010). Internal Diaspora-Assimilation-Formation of the Internal Diaspora. Acta Universitatis Sapientiae European and Regional Studies, 1(1), 59-82.

Babbie, E. (2008). A társadalomtudományi kutatás gyakorlata. Balassi Kiadó: Budapest.

Balizs, D. (2015). Ethnic structure, assimilation and identity in the historical Vas county. Ph.D.dissertation. University of Szeged, Faculty of Science and Informatics, Department of Economic and Social Geography.

Balizs, D., \& Bajmócy, P. (2015). Ethnic identity of the borderland of Hungary, Austria and Slovenia. Geographica Timisiensis, 24(1), 1-14.

Banks, J. A. (2004). Foreword. In Luchtenberg, S. (Ed), Migration, Education and Change. Roudledge: London-New York.

Bernstein, B. (2002). Nyelvi szocializáció és oktathatóság. In A. Jászó, A., Bódi, Z. (Ed.), Szociolingvisztikai szöveggyüjtemény (pp.185-195). Tinta Könyvkiadó: Budapest.

Boros, L. (2008). Spatial aspects of the urban deprivation - a conflict perspective approach and case studies on Szeged. Ph.D.dissertation. University of Szeged, Faculty of Science and Informatics, Department of Economic and Social Geography.

Bourdieu, P. (1996). Az oktatási rendszer ideologikus funkciója. In Melegh, C. (Ed), Iskola és társadalom I. Szöveggyüjtemény (pp. 10-24). Janus Pannonius Tudományegyetem: Pécs.

Brubaker, R. (2005). The "diaspora" diaspora. Ethnic and Racial Studies, 28(1), 1-29.

Clifford, J. (1994). Diasporas. Cultural Anthropology, 9(3), 302-338.

De Klerk, V. (2001). The Cross - Marriage Language Dilemma: His Language or Hers? International Journal of Bilingual Education and Bilingualism, 4(3), 197-216.

Dobos, F. (2011). Szociológiai kutatások a határon túli magyarság körében. Asszimilációs folyamatok az erdélyi, felvidéki, kárpátaljai és vajdasági magyarság körében 1996-2011. Research report. B Fókusz Intézet: Budapest. on 2015/09/14 from http://www.kmkf.hu/tartalom/assszimilacio.pdf14)

Đerčan, B., Bubalo-Živković, M., Solarević, M., \& Šabić, D. (2017). Living on the border: social indicators of life quality in Srem border region (Vojvodina, Serbia). Geographica Pannonica, 21(1), 26-42.

Djurdjev, S. B., Kicošev, S., \& Vuksanović, G. (2003). Strenghts and Weaknesses of Human Resources in Regional Development of Vojvodina Province. Geographica Pannonica, 7 , 21-26.

Ferenc, V. (2013). School choice in Subcarpathia: The case of Beregszász (Berehovo). Minority Studies: Demography, Minority, Education, Ethnopolitics, 15,161-184.

Filipović, J., Vučo, J., \& Djurić, L. (2007). Critical Review of Language Education Policies in Compulsory Primary and Secondary Education in Serbia. Current Issues in Language Planning, 8 (2), 222-242.

Göncz, L. (2006). Iskolaválasztás Vajdaságban. In Gábrity Molnár, I., Mirnics, Z. (Ed), Oktatási oknyomozó (pp. 125-141). Magyarságkutató Tudományos Társaság: Szabadka.

Göncz, L. (2014). Maintenance of languages and cultures of indigeneous communities in Central-Eastern-Europe through education: psycholinguistic and sociolinguistic 
perspectives. In Szalma, J. (Ed), Strateški pravci razvoja društvenih nauka, kultura $i$ umetnosti u Vojvodini do 2020. godine (pp. 56-80). Zbornik radova-2014. Vojvodanska Akademija Nauka i Umetnosti: Novi Sad.

Grosjean, F. (1982). Life with two languages: An introduction to bilingualism. Harvard University Press: Cambridge.

Haggett, P. (2006). Geográfia - Globális szintézis. Typotex Kiadó: Budapest.

Hajdú, Z., \& Szügyi, É. (2015). Szerbia. In Horváth, G. (Ed), Kelet-és Közép-Európa régióinak portréi (pp. 385-408). Kossuth Kiadó: Budapest.

Ilyés, Z. (2007). Researching and interpreting diaspora - Remarks on social science research into the diaspora communities of the Carpathian Basin. In Balogh, B., Ilyés, Z. (Ed), Perspectives of Diaspora Existence: Hungarian Diasporas in the Carpathian Basin Historical and Current Contexts of a Specific Diaspora Interpretation and Its Aspects of Ethnic Minority Protection (pp.47-65). Akadémiai Kiadó: Budapest.

Joó Horti, L., Mengyán Pletikoszity, I., Csernik, I., \& Badis, R. (2014). Magyar gyerek, szerb iskola, avagy a magyar oktatás vonzereje a Vajdaságban. Kisebbségkutatás, 23(4), 174187.

Kapitány, B. (2015). Ethnic Hungarians in the neighbouring countries. In Monostori, J., Öri, P., \& Spéder, Z. (Ed.), Demographic Portrait of Hungary 2015: Report on the Conditions of the Hungarian Population (pp. 225-239). Hungarian Demographic Research Institute: Budapest.

Kocsis, K., Bottlik, Z., \& Tátrai, P. (2006). Etnikai térfolyamatok a Kárpát-medence határainkontúli régióiban (1989-2002). Hungarian Academy of Sciences, Geographical Research Institute: Budapest.

Kozma, T., \& Tőzsér, Z. (2016). Education and Transition in Hungary: Policy and Research in the Process of Transformation, 1988-2004. Hungarian Educational Research Journal, 6(2), 24-42.

Kocsis, K., \& Kocsis-Hodosi, E. (1998). Ethnic Geography of the Hungarian Minorities in the Charpatian Basin. Geographical Research Institute, Research Centre for Earth Science and Minority Studies Programme, Hungarian Academy of Science: Budapest.

Kovács, Z. (2017). Bevezetés. Magyar Tudomány, 178(3), 258-260.

Kovačević, T., Zakić, L., \& Bubalo-Zivković, M. (2010). Age-gender strukture of Croats in Vojvodina Province. Journal of Studies and Research in Human Geography, 4(2), 63-78.

Laponce, J. (1987). Languages and their territories. University of Toronto Press: Toronto.

Léphaft, Á., Németh, Á., \& Reményi, P. (2014). Ethnic diversity and polarization in Vojvodina. Hungarian Geographical Bulletin, 63(2), 135-157.

Macnamara, J. (1967). The bilingual's linguistic performance - A psychological overview. Journal of Social Issues, 23(2), 58-77.

Malmberg, B., Andersson, E., \& Bergsten, Z. (2013). School Choice Motives: The Effects of Class and Residential Context. Working Paper.

http://www.su.se/polopoly_fs/1.156150.1384943996!/menu/standard/file/WP_2013_11.p df

(Rertieved 2018.03.15)

Mészáros, R. (2014). Some geographical connections of interdisciplinarity. Földrajzi Közlemények 138(4), 335-340.

Nagy, I. (2015). Szerbia térszerkezeti felosztása és annak tükröződése az egyetemi hallgatók mentális térképében. In Hardi, T. (Ed.), Terek és tér-képzetek: Elképzelt és formalizált terek, régiók a Kárpát-medencében, Közép-Európában (pp. 303-320). Fórum Kisebbségkutató Intézet - MTA KRTK Regionális Kutatások Intézete: Somorja- Győr.

Papp Z. A. (2013). Motivations for school choice and minority perspectives. Kisebbségkutatás, $15,99-122$. 
Papp Z. A. (2014). Selecting a majority-language school by Hungarian minority students, or from PISA Results to discourses in the Carpathian Basin. Minority Studies: Demography, Minority Education, Ethnopolitics, 17, 89-101. Retrieved on 2016/01/21 from http://real.mtak.hu/19903/1/papp_z_a_tobbsegi_nyelvu_iskolavalasztas_forditani_hu_en 2_pza_is.pdf

Petitto, L. A., Katerelos, M., Levy, B.G., \& Gauna, K., (2001). Bilingual signed and spoken language acquesition from birth: implications for the mechanism under lying early bilingual language acquisition. Journal of Child Language, 28(2), 453-496.

Priestly, T. (1994). Effects of educational and social mobility on language maintenance, language attitudes and language structure: The case of Sele in Carinthia. Journal of Multilingual and Multicultural Development, 15(2-3), 199-217.

Skutnabb-Kangas, T. (1981). Bilingualism or Not: The Education of Minorities. Avon Multilingual Matters Ltd.: Clevedon.

Schneider, M., \& Buckley. J. (2002). What do parents want from schools? Evidence from the Internet. Educational Evaluation and Policy Analysis, 24(2),133-144.

Szerbhorváth, G. (2015). A kisebbségi nyelvi jogok Vajdaságban - jog és valóság. Pro Minoritate, 2015 (autumn), Retrieved on 2016/10/25 from http://www.prominoritate.hu/folyoiratok/2015/ProMino-1503-05-Szerbhorvath.pdf

Szügyi, É. (2012). Choice of school in Voivodina. Kisebbségkutatás, 21(3), 514-535.

Szügyi, É. (2013). Regions and regionalism in Serbia. Deturope, 5(3), 105-126.

Takács, Z. (2008). A munkaerö-kompetencia és az oktatás viszonya. In Gábrity Molnár, I., Mirnics, Z. (Ed), Regionális erönlét. A humáneröforrás befolyása Vajdaságban (pp. 267293). Magyarságkutató Tudományos Társaság: Szabadka.

Tátrai, P. (2017). A Kárpát-medencei magyar szórványok településszerkezete és főbb demográfiai jellemzői. Kisebbségi Szemle, 2(1), 7-34.

Vajda, Z., \& Kósa, É. (2005). Neveléslélektan. Osiris Kiadó: Budapest.

\section{Sources and statistical database}

Education Development Strategy 2010-2016, National Council of the Hungarian Ethnic Minority

Source: http://www.profturchany.eu/documents/UIDD_hu_Vajdasagi_okt_fejl.pdf

(2011.09.10)

Statistical Office of the Republic of Serbia (RZS), 2011

Source: http://webrzs.stat.gov.rs/WebSite/Default.aspx

(2015.03.10.)

The Republic of Serbia: The Third Periodical Report on the Implementation of the European Charter for Regionalor Minority Languages in the Republic of Serbia, Belgrade, December 2014 (Republika Srbija: Treći periodičn izveštaj o primeni Evropske Povelje o regionalnim ili manjinskim jezicima u RebupliciSrbiji, Beograd, decembar, 2014) (in Serbian)

Source: http://www.ljudskaprava.gov.rs/sh/node/20001

(2016.07.10)

The Law on Primary Education (Zakon o osnovamasistemaobrazovanja i vaspitanja, "Sl. Glasnik RS", br. 88/2017 i 27/2018)

Source: www.mp.gov.rs (2018.02.01.)

The Law on Secondary Education (Zakon o srednjem obrazovanju i vaspitanju,"Sl. glasnik RS", br. 55/2013 i 101/2017)

Source: www.mp.gov.rs (2018.02.01.) 